\title{
Modeling Self-Regulated Learning: The mediating role in the relationship between academic procrastination and problematic smartphone use among third year-middle school learning disabled students
}

\section{Mourad Ali Eissa ${ }^{1}$ \& Ayman Gamal Khalifa ${ }^{2}$}

${ }^{1}$ KIE University

2 TVTC Directorate of Research and Studies

\section{Egypt}

Saudi Arabia 


\begin{abstract}
Introduction. Inability to self-regulate learning is likely to be an indication of internet/mobile phone use. When students have low self-regulation, this may negatively predict problematic smartphone use. Additionally, problematic smartphone use could be a predictor of academic procrastination. The aim of this study was to investigate the mediating role of self-regulated learning in the relationship between academic procrastination and problematic smartphone use among third year-middle school learning disabled students.
\end{abstract}

Method. For the purpose of this study, quantitative survey research was employed. The independent variable is AP, PSU is the dependent variable and SRL is the moderating variable. 228 students from the four schools were selected. They were all in third year. They aged 1415 years.

Results. Self-regulated learning correlates negatively with academic procrastination, and smartphone addiction. On the other hand, self-regulated learning was found to be positively correlated with Problematic Smartphone Use. This study found that academic procrastination predicted negatively self-regulated learning. SLR predicted AP.

Discussion and Conclusion. The results of this study raised our awareness of the mediating role of self-regulated learning in the relationship between academic procrastination and problematic smartphone use among third year-middle school learning disabled student.

Keywords. Self-Regulated Learning, Academic Procrastination, Problematic Smartphone Use, Third Year- Middle School Learning Disabled Students 


\section{Resumen}

Introducción. Es probable que la incapacidad para autorregular el aprendizaje sea un indicador del uso de Internet / teléfonos móviles. Cuando los estudiantes tienen poca autorregulación, esto puede predecir negativamente el uso problemático de teléfonos inteligentes. Además, el uso problemático de teléfonos inteligentes podría predecir la procrastinación académica. El objetivo de este estudio fue investigar el papel mediador del aprendizaje autorregulado en la relación entre la procrastinación académica y el uso problemático de teléfonos inteligentes entre estudiantes con dificultad de aprendizaje de tercer año de secundaria.

Método. Para el propósito de este estudio, se empleó investigación cuantitativa de encuestas. La variable independiente es AP, PSU es la variable dependiente y SRL es la variable moderadora. Se seleccionaron 228 estudiantes de las cuatro escuelas. Todos estaban en tercer año. Tenían entre 14 y 15 años.

Resultados. El aprendizaje autorregulado se correlaciona negativamente con la procrastinación académica y la adicción a los teléfonos inteligentes. Por otro lado, se descubrió que el aprendizaje autorregulado se correlaciona positivamente con el uso problemático de teléfonos inteligentes. Este estudio encontró que la procrastinación académica predijo el aprendizaje autorregulado negativamente. SLR predijo AP.

Discusión y conclusión. Los resultados de este estudio aumentaron nuestra conciencia sobre el papel mediador del aprendizaje autorregulado en la relación entre la procrastinación académica y el uso problemático de teléfonos inteligentes entre los estudiantes con discapacidad de aprendizaje de tercer año de secundaria.

Palabras clave. Aprendizaje autorregulado, dilación académica, uso problemático de teléfonos inteligentes, tercer año: estudiantes con discapacidades de aprendizaje en la escuela secundaria 


\section{Introduction}

Smartphone use has become part and parcel, that is an essential, basic element or an integral part of everyday life. Although smartphone applications are likely to be a source of convenience and entertainment for the users (students),they may have negative effects on their academics .There are many terms characterize the excessive use of smartphones, such as proneness to smartphone addiction, smartphone overuse ,excessive smartphone use, problematic mobile phone use, mobile phone dependence, and mobile phone addiction (Dmitri , Kristiina \&Karin,2018).

This overuse is accompanied by symptoms that is likely to resemble those found in contemporary addiction models: dependence, withdrawal, tolerance, and functional impairment (Dmitri et al.,2018). Accordingly, this phenomenon may be conceptualized as problematic smartphone use (PSU).

Problematic smartphone use occurs when a person (a student here) spends too much time using or playing with his smartphone and this overuse imposes some negative effects on life (Shahrestanaki, et al.,2020), such as low academic performance, poor sleep quality, anxiety, depression, low self-esteem, decreased communication competence, less exercise, neck pain, wrist pain and blurred vision(Adil, Talal \& Asma ,2020).

PSU is associated with negative outcomes such as low academic achievement and distraction from the learning process (Gugushvili et al.,2020). As shown by Ifeanyi \& Chukwuere (2018), it distracted students from their studies in certain aspects. Smartphone addiction, or "Internet Gaming Disorder" can be a problematic behavior, according to DSM-5, but in order to be considered a formal addictive disorder, much research should be conducted (APA, 2013).

\section{The influence of problematic smartphone use (PSU) on academic procrastination (AP)}

Procrastination is considered to be a negative phenomenon that has remarkable impact students' academic performance. It can be described as a student's intention to carry out a certain academic task but has problems in getting motivated to do within the specified time (Adel, A sharaf ,Mourad \& Amaal,2013;Fathi \& Mourad ,2015).These delays lead to invaria- 
bly inefficient or poor performance of students in their given task (Ferrari, O'Callaghan\& Newbegin,2005).High AP can lead to a dramatic decline in student learning performance(Wayan, Ketut \& Wayan,2020).In the domain of Internet use, students' high levels of Facebook use were found to be correlated with higher levels of academic procrastination(Sahin,2014).In a study of Chinese university students(Yang, Asbury\& Griffiths,2018),it was revealed that PSU predicted academic procrastination. PSU mediated the relationships between self-regulation, and both academic anxiety and academic procrastination. Ayça, İlknur \& Tuğba (2019) found that problematic smartphone use impacts academic procrastination. It was indicated that " problematic smartphone use " could be a predictor of academic procrastination (Ufuk, Mustafa, Süleyman \& Kübra,2013). It can be concluded that the influence of PSU on AP has been both theoretically and empirically supported.

\section{The influence of Self-Regulated Learning (SRL) on PSU}

SLR is correlated with adolescents' learning levels and academic results and performance (de la Fuente, 2017, 2019; de la Fuente et al., 2019; Fuentes et al., 2019; MartínezVicente \& De la fuente, 2004; Zapata et al, 2016). There is a significant correlation between self-regulation and addiction among teenager (Kwan \& Leung ,2017). The lower students' SRL is, the more they have smartphone addiction (Bogoan, Seok-won, Hwajung \& Kyungsik, 2019). SRL predicted Problematic Smartphone Use (Zeyang, Kathryn \& Mark, 2019). People's inability to self-regulate their learning might increase their smartphone usage (Penjira, Felicito, Ruangrit, \& Penjuree ,2016). Inability to self-regulate learning is likely to be an indication of internet/mobile phone use (Soror ,Steelman, \& Limayem ,2012). When students have low self-regulation, this may negatively predict problematic smartphone use, as has been found in European samples (Gökçearslan, et al., 2016). The results of Lee, Cho, Kim \& Noh 's study (2015), in consistent with others' (e.g. Kim, Tak, \& Lee, 2010; Sha, Looi, Chen, \& Zhang, 2012) indicated that students who used smartphone less could have more SRL strategies and average learning flow, compared to those with those who are regarded as smartphone addicted .

\section{Aims and Hypotheses}

Based upon the aforementioned theoretical and empirical literature, there are some issued that should be resolved, especially in the context of learning disabilities. The mediating role of SLR in the relationship between PSU and AP should be investigated, as well as the inter-correlations between and among these variables. Four hypotheses are proposed: (i) PSU 
will positively predict AP, (ii) SRL will positively predict AP, (iii) PSU will positively predict AP mediated via SRL, and (iv) SRL will negatively predict PSU. These hypotheses are presented as a hypothesized model in Figure 1.

$\mathrm{H} 4$

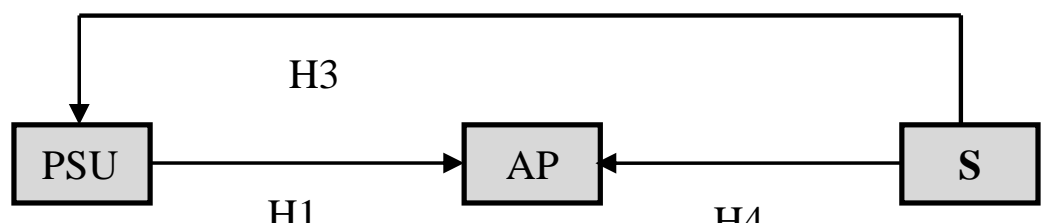

$\mathrm{H} 4$

Figure 1. Model of hypotheses

\section{Method}

Design

For the purpose of this study, quantitative survey research was employed. The independent variable is AP, PSU is the dependent variable and SRL is the moderating variable

\section{Participants}

Convenient sampling method was used to recruit the participants. The researcher selected six middle schools from Baltim City, Kafr El Sheihk, namely Martada Basic Education School, Al waheba middle School, El Aiash El Gharbi middle School and El Aiash El Sharki middle school, El Sabeia middle school, and El Baneieen middle school. The researcher confirmed that any information students would provide would be top secret and confidential. It would not be revealed to anyone. It would be used for research purpose only. Each student participant met the criteria for specific learning disorder. Those who demonstrated low achievement scores on a cognitive reading comprehension test (standardized test Mourad, 2015) (i.e., at least 1.5[SD] below their same age people(APA, 2013, P.70 ; Mourad, 2018, P.109), though their normal levels of intellectual functioning(Mourad, 2012; Mourad \& Amaal, 2013; Hesham\& Rasha, 2014; ),the absence of any neurological or motor disorders (Al Said, 2014; Mohammed, 2014; Omema, 2015) were included. So 228 students from the four schools were selected. They were all in third year. They aged 14-15 years $(M=14.6, S D=$ 1.12). 


\section{Instruments}

Brief Smartphone Addiction Scale (BSAS) (Csibi, Demetrovics \& Szabo ,2016). The purpose of this scale was to assess exaggerated smartphone use. It is 6 items with a 6-point Likert scale from $1=$ strongly disagree, $6=$ strongly agree. The scale takes only 5 minutes to complete. Total scores typically range from 6 - 36. Principal components analysis yielded a single component for the 6 -item tool, which accounted for $52.38 \%$ of the total variance. The internal reliability of the scale was good $(\alpha=0.82)$. Content validity was achieved as there were significant differences between heavy and light users $(p<.001)$ (Csibi et al. 2016). The content validity of the scale was examined by a group of 10 experts. They assessed the relevance of each item using a four-point Likert scale (where 1 represents "irrelevant" and 4 represents "highly relevant"). They provided suggestions and comments. The 6 items were judged to be quite or highly relevant. A content validity index was calculated at the item level $(\mathrm{I}-\mathrm{CVI}=0.90)$. In this study, the internal reliability of the scale was good too $(\alpha=0.85)$.

Self-Regulated Learning Scale. This scale was developed specifically for this study. It is a10 items with a 4 -point Likert scale from $1=$ Not very like me, $4=$ very like me. The scale takes only 10 minutes to complete. Total scores typically range from $10-40$. The internal reliability of the scale was good $(\alpha=0.89)$. Content validity was achieved as there were significant differences between high and low self regulated students $(p<.001)$. The content validity of the scale was examined by a group of 10 experts. They assessed the relevance of each item using a four-point Likert scale (where 1 represents "irrelevant" and 4 represents "highly relevant"). They provided suggestions and comments. The 10 items were judged to be quite or highly relevant. A content validity index was calculated at the item level $(I-C V I=0.90)$.

Procrastination Scale (Tuckman,1991). The purpose of this scale was to assess procrastination tendencies. It is a 16 items with a 4-point Likert (i.e. $1=$ that's me for sure, 2 =that's my tendency, $3=$ that's not my tendency,4= that's not me for sure). Total scores typically range from $16-64 . \alpha=.86$. The content validity of the scale was examined by a group of 10 experts. They assessed the relevance of each item using a four-point Likert scale (where 1 represents "irrelevant" and 4 represents "highly relevant"). They provided suggestions and comments. The 16 items were judged to be quite or highly relevant. A content validity index was calculated at the item level $(I-C V I=0.90)$. 


\section{Procedures}

Prior to administering the scales, the researcher informed students' parents with the help of social work teacher. They were given the option of accepting or refusing to allow their children's participation in the study. Students were also informed about purpose of the study. The researcher instructed them to honestly complete the scales. They were told to keep their identifies anonymous on the scale paper to ensure honesty and sincerity. They also were informed that they should participate voluntarily and nothing to be feared about even their responses. All data were entered in an SPSS file.

\section{Data analysis}

Pearson correlation and moderated hierarchical multiple regression analyses were conducted to test the hypotheses of the study.

\section{Results}

\section{Descriptive data and inter-correlations}

Table 1 shows the means, descriptive statistics, inter-correlations, and internal consistency coefficients of self-regulated learning, academic procrastination and Problematic Smartphone Use. Self-regulated learning correlates negatively with academic procrastination $(r=-0.53)$, and smartphone addiction $(r=-0.49)$. On the other hand, self-regulated learning was found to be positively correlated with Problematic Smartphone Use $(r=0.41)$.

Table 1. Descriptive statistics and inter-correlations of self-regulated learning, academic procrastination and Problematic Smartphone Use.

\begin{tabular}{lccc}
\hline Variables & 1 & 2 & 3 \\
\hline SRL & 1.00 & & \\
AP & $-.53^{* *}$ & 1.00 & \\
PSU & $-.49^{* *}$ & $.41^{* *}$ & 1.00 \\
Mean & 29.57 & 32.19 & 47.65 \\
Standard deviation & 3.60 & 1.07 & 2.75 \\
\hline$* * p<.01$ & & &
\end{tabular}

Note. SRL (self-regulated learning), AP (academic procrastination), PSU (Problematic Smartphone Use) 
Testing the mediating role of SLR in the relationship between PSU and AP

From tables $2-4$, it is clear that $R^{2}=.677$, Adjusted $R^{2}=.669$, which means that the independent variable, SLR, explains $66.9 \%$ of the variability of the dependent variable, PSU. The regression model is statistically significant, $F=9.867, p=.002$. This indicates that, overall, the model applied can statistically significantly predict the dependent variable, PSU.

From tables 5-7, it is clear that $R^{2}=.677$, Adjusted $R^{2}=.669$, which means that the independent variable, SLR, explains $66.9 \%$ of the variability of the dependent variable, AP. The regression model is statistically significant, $F=9.869, p=.002$. This indicates that, overall, the model applied can statistically significantly predict the dependent variable, AP.

Table 2. The regression results of the relationship between SLR and PSU. Model Summary b

\begin{tabular}{|c|c|c|c|c|c|c|c|c|c|}
\hline \multirow[t]{2}{*}{ Model } & \multirow[t]{2}{*}{$\mathrm{R}$} & \multirow{2}{*}{$\begin{array}{l}\text { R Squa- } \\
\text { re }\end{array}$} & \multirow{2}{*}{$\begin{array}{l}\text { Adjusted } \\
\text { R Square }\end{array}$} & \multirow{2}{*}{$\begin{array}{l}\text { Std. Error } \\
\text { of the } \\
\text { Estimate }\end{array}$} & \multicolumn{5}{|c|}{ Change statistics } \\
\hline & & & & & $\begin{array}{l}\text { R Squa- } \\
\text { re } \\
\text { change }\end{array}$ & $\begin{array}{l}\text { F Chan- } \\
\text { ge }\end{array}$ & Df1 & Df2 & $\begin{array}{l}\text { Sig. F } \\
\text { change }\end{array}$ \\
\hline 1 & $0.478 \mathrm{a}$ & 0.677 & 0.669 & 11.73011 & 0.677 & 9.867 & 1 & 118 & 0.002 \\
\hline
\end{tabular}

a. Predictor (constant), SLR

b. Dependent variable: PSU.

Table 3. The regression results of the relationship between SLR and PSU (ANOVA)

\begin{tabular}{llllll}
\hline Model & Sum of Squares & $d f$ & Mean Square & $F$ & Sig. \\
\hline 1 Regression & 1357.703 & 1 & 1357.706 & 9.867 & $0.002 a$ \\
Residual & 16236.260 & 226 & 137.595 & & \\
Total & 17593.967 & 227 & & & \\
\hline
\end{tabular}

a. Predictor (constant), SLR

b. Dependent variable: PSU.

Table 4. The regression results of the relationship between SLR and PSU. Coefficients a

\begin{tabular}{|c|c|c|c|c|c|c|c|c|}
\hline \multirow[t]{2}{*}{ Model } & \multicolumn{2}{|c|}{$\begin{array}{l}\text { Unstandarized coef- } \\
\text { ficients }\end{array}$} & \multirow{2}{*}{$\begin{array}{c}\begin{array}{c}\text { Standarized } \\
\text { coefficients }\end{array} \\
\text { Beta }\end{array}$} & \multirow[t]{2}{*}{$\mathrm{t}$} & \multirow[t]{2}{*}{ sig } & \multicolumn{3}{|c|}{ Correlations } \\
\hline & B & Std error & & & & Zero-order & Partial & part \\
\hline 1 (constant) & 114.304 & 14.298 & & 7.994 & .000 & 278 & 278 & 278 \\
\hline SLR & -.349 & .111 & -.279 & -3.141 & .002 & .210 & .210 & .21 \\
\hline
\end{tabular}

b. Dependent variable: PSU. 
Table 5. The regression results of the relationship between SLR and AP Model Summary b

\begin{tabular}{|c|c|c|c|c|c|c|c|c|c|}
\hline \multirow[t]{2}{*}{ Model } & \multirow[t]{2}{*}{$\mathrm{R}$} & \multirow{2}{*}{$\begin{array}{l}\text { R Squa- } \\
\text { re }\end{array}$} & \multirow{2}{*}{$\begin{array}{l}\text { Adjusted } \\
\text { R Square }\end{array}$} & \multirow{2}{*}{$\begin{array}{l}\text { Std. Error } \\
\text { of the } \\
\text { Estimate }\end{array}$} & \multicolumn{5}{|c|}{ Change statistics } \\
\hline & & & & & $\begin{array}{l}\text { R Square } \\
\text { change }\end{array}$ & $\begin{array}{c}\mathrm{F} \\
\text { Change }\end{array}$ & Df1 & Df2 & $\begin{array}{l}\text { Sig. F } \\
\text { change }\end{array}$ \\
\hline 1 & $0.478 \mathrm{a}$ & 0.677 & 0.669 & 8.71891 & .677 & 9.869 & 1 & 118 & .002 \\
\hline
\end{tabular}

a. Predictor (constant): SLR

b. Dependent variable: AP

Table 6. The regression results of the relationship between SLR and AP. ANOVA

\begin{tabular}{lccccc}
\hline Model & Sum of Squares & df & Mean Square & F & Sig. \\
\hline 1 Regression & 750.211 & 1 & 750.211 & 9.869 & .002 \\
Residual & 8970.289 & 226 & 70.019 & & \\
Total & 9720.500 & 227 & & & \\
\hline
\end{tabular}

a. Predictor (constant): SLR

b. Dependent variable: AP

Table 7. The regression results of the relationship between SLR and AP. Coefficients a

\begin{tabular}{|c|c|c|c|c|c|c|c|c|}
\hline \multirow[t]{2}{*}{ Model } & \multicolumn{2}{|c|}{$\begin{array}{l}\text { Unstandarized coef- } \\
\text { ficients }\end{array}$} & \multirow{2}{*}{$\begin{array}{c}\text { Standarized coef- } \\
\text { ficients } \\
\text { Beta }\end{array}$} & \multirow[t]{2}{*}{$\mathrm{t}$} & \multirow[t]{2}{*}{ sig } & \multicolumn{3}{|c|}{ Correlations } \\
\hline & B & $\begin{array}{l}\text { Std } \\
\text { error }\end{array}$ & & & & $\begin{array}{l}\text { Zero- } \\
\text { order }\end{array}$ & Partial & part \\
\hline $\begin{array}{l}1 \\
\text { ( constant) }\end{array}$ & 91.542 & 10.628 & -.278 & 8.614 & .000 & -.278 & -.278 & -.278 \\
\hline SLR & 0.295 & 0.083 & & 3.141 & .002 & & & \\
\hline
\end{tabular}

b. Dependent variable: AP

According to table 8, as for the effect of AP on SLR, the probability of getting a critical ratio as large as 3.155 in absolute value is 0.002 . In other words, the regression weight for AP in the prediction of SLR is significantly different from zero at the 0.01 level (twotailed).As to the effect of SLR on PSU, the probability of getting a critical ratio as large as 2.787 in absolute value is 0.005 . In other words, the regression weight for SLR in the prediction of PSU is significantly different from zero at the 0.01 level (two-tailed). When the mediator (SLR) mediates between PSU and AP, the probability of getting a critical ratio as large as 0.915 in absolute value is 0.360 . In other words, the regression weight for PSU in the prediction of AP is not significantly different from zero at the 0.05 level (two-tailed). This means that the relationship between independent variable (PSU) and dependent variable (AP) became insignificant. This also means that emotional intelligence is a mediator between PSU and AP, and this mediation is complete one. 
Table 8. Regression Weights: (Group number 1 - Default model)

\begin{tabular}{lllllll}
\hline & & Estimate & S.E. & C.R. & P & Label \\
\hline SLR <--- & AP & -.298 & .094 & -3.155 & .002 & \\
PSU <--- & SLR & -.320 & .115 & -2.787 & .005 & \\
PSU <--- & AP & .112 & .123 & .915 & .360 & \\
\hline
\end{tabular}

\section{Discussion}

The present study aimed to investigate the mediating role of self-regulated learning in the relationship between academic procrastination and problematic smartphone use among third year-middle school learning disabled students.

Descriptive statistics, inter-correlations, and internal consistency coefficients of selfregulated learning, academic procrastination and smartphone addiction showed that selfregulated learning correlates negatively with academic and smartphone. On the other hand, self-regulated learning was found to be positively correlated with smartphone addiction. Although is inconsistent with the finding obtained by Penjira et al.(2016), which revealed that self-regulation had no significant effect on smartphone addiction, the findings of this study confirm previous other research that when students have higher levels of addiction, this is an indicator of having lower level of self -regulated learning, as well as low level of flow when studying (Lee et al., 2015).

This study found that academic procrastination predicted negatively self-regulated learning. In line with previous studies (Gökçearslan et al., 2016; LaRose \& Eastin, 2004; LaRoseetal, 2003; Soror et al., 2012; Van Deursen et al., 2015), SLR predicted AP. It seems that the students in the present study were more likely to procrastinate when they were not able to regulate their learning, hence, they could not or did not control their smartphone use. self-regulation may play a substantial role in smartphone addiction, as the dependence on smartphone is the result of uncontrolled and uncontrollable behavior (Kwan \& Leung, 2017). 


\section{Application and implications}

The results of this study raised our awareness of the mediating role of self-regulated learning in the relationship between academic procrastination and problematic smartphone use among third year-middle school learning disabled student .They also raised our awareness of the negative impact that problematic smartphone use has upon learning disabled students ,as those with low risk for problematic smartphone use could have higher average self-regulated learning, and vise versa. Additionally, students who have been highly prone to problematic smartphone use are rarely able to attain high academic achievement and may delay doing their assigned homework.

\section{Conclusion}

In conclusion, the aim of this study was to investigate the mediating role of selfregulated learning in the relationship between academic procrastination and problematic smartphone use among third year-middle school learning disabled students. It can be concluded that students who overuse smartphones procrastinate academic work, and they cannot be able to regulate their learning. Smartphone addiction prevent students from effective studying and time management (Serkan \&Eken, 2018). The study findings expand our knowledge of the mediating role of self-regulated learning in the relationship between academic procrastination and problematic smartphone use among third year-middle school learning disabled students.

\section{References}

Adel M., sharaf A., Mourad A. \& Amaal A. (2013). Academic procrastination among college students with learning disabilities: The role of positive and negative self - oriented perfectionism in terms of gender, specialty and grade. Psycho-Educational Research Reviews 2 (1):2-12.

Adil M., Talal A. \& Asma S. (2020). The prevalence of smartphone addiction and its correlation with depression among higher college of technology students, Oman. AL Mahrooqi AM et al. Int $J$ Res Med Sci. 8(5),1833-1837.

Al Said, A. (2014). The Effect of Metacognitive Strategy Training on Student Mathematical ProblemSolving Process and Contemplative Thinking Skills in Primary School Children with Learning Disabilities. Psycho-Educational Research Reviews 3 (2):3 - 11.

American Psychiatric Association. (2013). Internet Gaming Disorder. American Psychiatric Association DSM-V Development. Retrieved August 30, 2016, from http://www.dsm5.org/Documents/Internet\%20Gaming\%20Disorder\%20Fact\%20Sheet.pdf 
Ayça, Ç., İlknur, R. \& Tuğba, T. (2019). The Relationships among Academic Procrastination, SelfControl, and Problematic Mobile Use: Considering the Differences over Personalities. Addicta: The Turkish Journal on Addictions, 6, 447-468. http://dx.doi.org/10.15805/addicta.2019.6.3.0082

Bogoan, K. Seok-won, L. Hwajung, H. \& Kyungsik, H. (2019). Automated Time Manager: Effectiveness of Self-Regulation on Time Management Through a Smartphone Application. IEEE Access PP (99),1-1. DOI: 10.1109/ACCESS.2019.2926743.

Csibi, S., Demetrovics, Z., \& Szabo, A. (2016). Hungarian adaptation and psychometric characteristics of Brief Addiction to Smartphone Scale (BASS). Psychiatria Hungarica, 31(1), 71-77.

de la Fuente, J. (2017). Theory of self- vs. externally-regulated learningTM: fundamentals, evidence, and applicability. Front. Psychol. 8,1675. doi: 10.3389/fpsyg.2017.01675

de la Fuente, J. (2019). The UtilityModel for the SRL vs ERL Theory. TradeMark in Process. Pamplona: University of Navarra.

de la Fuente J, Martínez-Vicente J.M., Peralta-Sánchez F.J., Garzón-Umerenkova A., Vera M. \& Paoloni, P. (2019) Applying the SRL vs. ERL Theory to the Knowledge of Achievement Emotions in Undergraduate University Students. Front. Psychol. 10:2070. doi: 10.3389/fpsyg.2019.02070

Dmitri R., Kristiina S., \& Karin T. (2018). Problematic Smartphone Use, Deep and Surface Approaches to Learning, and Social Media Use in Lectures. International journal of environmental research and public health, 15(1), 92.

Fathi A. \& Mourad A. (2015). Academic Procrastination and Five Factor Personality Traits among College Students. Psycho-Educational Research Reviews 4 (2):10 - 15.

Ferrari, J. R., O'Callaghan, J., \& Newbegin, I. (2005). Prevalence of procrastination in the United States, United Kingdom, and Australia: Arousal and avoidance delays among adults. North American Journal of Psychology,7(1), 1-6.

Fuentes, M., C., García-Ros, R., Pérez-González, F., \& Sancerni (2019). Effects of Parenting Styles on Self-Regulated Learning and Academic Stress in Spanish Adolescents. Int. J. Environ. Res. Public Health, 16, 2778; doi:10.3390/ijerph16152778.

Gökçearslan, Ş., Mumcu, F. K., Haşlaman, T., \& Çevik, Y. D. (2016). Modelling smartphone addiction: The role of smartphone usage, self-regulation, general self-efficacy and cyberloafing in university students. Computers in Human Behavior, 63, 639-649.

Gugushvili, N., Täht, K., Rozgonjuk, D., Raudlam, M., Ruiter, R. \& Verduyn, P. (2020). Two dimensions of problematic smartphone use mediate the relationship between fear of missing out and emotional well-being. Cyberpsychology: Journal of Psychosocial Research on Cyberspace, 14(2), Article 3. https://doi.org/10.5817/CP2020- 2-3 
Hesham, H. \& Rasha, M. (2014). Effectiveness of Differentiated Instruction on Achievement in Mathematics of Middle School Students with Learning Disabilities. Psycho-Educational Research Reviews 3 (1):29 - 34.

Ifeanyi, I. P., \& Chukwuere, J. E. (2018). The impact of using smartphones on the academic performance of undergraduate students. Knowledge Management \& E-Learning, 10(3), 290-308.

Kim, A., Tak, H., \& Lee, C. (2010). The development and validation of a learning flow scale for adults. Educational Psychology Research, 39-59.

Kwan H.\&Leung M. (2017). The Structural Model in Parenting Style, Attachment Style, Selfregulation and Self-esteem for Smartphone Addiction. IAFOR Journal of Psychology \& the Behavioral Sciences,3(1), 85-103.

LaRose, R., \& Eastin, M. S. (2004). A social cognitive theory of Internet uses and gratifications: Toward a new model of media attendance. Journal of Broadcasting \& Electronic Media, 48(3), $358-377$.

LaRose, R., Lin, C. A., \& Eastin, M. S. (2003). Unregulated Internet usage: Addiction, habit, or deficient self regulation? Media Psychology, 5(3), 225-253.

Lee, J., Cho, B., Kim, Y., \& Noh, J. (2015). Smartphone addiction in university students and its implication for learning. In Emerging issues in smart learning. (pp. 297-305). Berlin, Heidelberg: Springer.

Martínez-Vicente, J. M. \& de la Fuente, J. (2004). Self-regulation of Learning through the Pro\&Regula Program. Electronic Journal of Research in Educational Psychology, 2 (1), 145156.

Mohammed, A. (2014). The Effect of Differentiating Instruction using Multiple Intelligences on Improving Reading Comprehension of 5th Graders with Learning Disabilities. PsychoEducational Research Reviews 3 (2):12 - 20.

Mohammed, F.(2019). Egyptian Validation of Smartphone Addiction Scale Short Version for Adolescents (SAS-SV). Psycho-Educational Research Reviews, 9 (1), 7- 10.

Mourad A. (2012). The Effects of Advance Graphic Organizers Strategy Intervention on Academic Achievement, Self Efficacy, and Motivation to Learn Social Studies in Learning Disabled Second Year Prep Students. Psycho-Educational Research Reviews 1 (1):11-21

Mourad A. (2015). The Effectiveness of a Self Regulated Learning-Based Training Program on Improving Cognitive and Metacognitive EFL Reading Comprehension of 9th Graders with Reading Disabilities. Psycho-Educational Research Reviews ,4(3),49-59.

Mourad A. (2018). Issues related to identification of children with specific learning disorders (SLDs): insights into DSM-5. Psycho-Educational Research Reviews, 7 (1), 106-111.

Mourad, A. \& Amaal, M. (2013). The Effects of Differentiated Instruction by Integrating Multiple Intelligences and Learning Styles on Solving Problems, Achievement In, and Attitudes To- 
Modeling Self-Regulated Learning: The Mediating Role In The Relationship Between Academic Procrastination And Problematic Smartphone Use Among Third Year-Middle School Learning Disabled Students

wards Math in Six Graders with Learning Disabilities in Cooperative Groups . PsychoEducational Research Reviews 2 (2):31 - 43.

Omema, M. (2015). The Effect of Reciprocal Teaching Intervention Strategy on Reading Comprehension Skills of 5th Grade Elementary School Students with Reading Disabilities. PsychoEducational Research Reviews, 4(2), 39-45.

Penjira, K., Felicito, F., Ruangrit, R. \& Penjuree, K. (2016). An empirical study on the impact of selfregulation and compulsivity towards smartphone addiction of university students. 13th International Conference on Cognition and Exploratory Learning in Digital Age (CELDA 2016).

Sahin, Y. L. (2014). Comparison of users' adoption and use cases of Facebook and their academic procrastination. Digital. Education Review, 25, 127-138.

Serkan, D. \&Eken, E. (2018). Investigation of Smartphone Addiction Among University Students in Terms of Academic Achievement, Academic Procrastination, Smartphone Usage Behaviors and Some Demographic Variables. Conference: 27th International Congress on Educational Sciences At: Antalya/Turkey.

Sha, L., Looi, C., Chen, W., \& Zhang, B. (2012). Understanding mobile learning from the perspective of self-regulated learning. Journal of Computer Assisted Learning, 28, 366-378. https://doi.org/10.1111/j.1365-2729.2011.00461.x

Shahrestanaki, E., Maajani, K., Safarpour, M., Ghahremanlou, H. H., Tiyuri, A., \& Sahebkar, M. (2020). The relationship between smartphone addiction and quality of life among students at Tehran University of medical sciences. Addicta: The Turkish Journal on Addictions, 7(1), 6166

Soror, A. A., Steelman, Z. R., \& Limayem, M. (2012). Discipline yourself before life disciplines you: Deficient self-regulation and mobile phone unregulated use. In: System Science (HICSS), 2012 45th Hawaii International Conference on (pp. 849-858). New Jersey: IEEE

Tuckman, B. (1991). The development and concurrent validity of the procrastination scale. Educational and Psychological Measurement, 51, 473-480.

Ufuk, E., Mustafa, P., Süleyman, E. \& Kübra, P. (2013). Academic Procrastination and Mobile Phone (was presented as oral at International Academic Conference on Education, Teaching and Elearning, Prague,17-18 October 2013).

Van Deursen, A. J., Bolle, C. L., Hegner, S. M., \& Kommers, P. A. (2015). Modeling habitual and addictive smartphone behavior: The role of smartphone usage types, emotional intelligence, social stress, self regulation, age, and gender. Computers in Human Behavior, 45, 411-420

Wayan, I., Ketut, N.\& Wayan, I. (2020). Project Based Learning and Academic Procrastination of Students in Learning Physic. International Journal of Instruction, 13(1), 489-508.

Yang, Z., Asbury, K. \& Griffiths, M. (2018) An exploration of problematic smartphone use among Chinese university students: Associations with academic anxiety, academic procrastination, self-regulation, and subjective wellbeing. Journal of Mental Health and Addiction,1-19. 
Zapata, L., De la Fuente, J., Martínez-Vicente, J.M., González, M. C., \& Artuch, R. (2016). Relations between the personal self-regulation and learning approach, coping strategies, and selfregulation learning, in university students (process). International Journal of Developmental and Educational Psychology, 1(4). 175-186

Zeyang, Y., Kathryn, A. \& Mark, A. (2019). An Exploration of Problematic Smartphone Use among Chinese University Students: Associations with Academic Anxiety, Academic Procrastination, Self-Regulation and Subjective Wellbeing. Int J Ment Health Addiction, 17, 596614https://doi.org/10.1007/s11469-018-9961-1

Received: $27-12-2019$

Accepted: $13-08-2020$ 